\title{
Analysis Of The Utilization of Covid 19 Poster Media in Learning Narrative Writing in Class IV Students of SDN Keseneng
}

\section{Khoirunnisaq}

SD Negeri Keseneng

khoirunnisaq@gmail.com

Article History

accepted 14/11/2020

approved $21 / 11 / 2020$

published 26/11/2020

\begin{abstract}
This research is a quantitative research. This research method uses phenomenological research methodology, to explore the phenomena that occur and their novelty. This study aims to describe the feasibility of the Covid 19 alert poster as a medium in learning to write narrative for fourth grade students of SD Negeri Keseneng. In addition, this study also aims to determine student responses to the use of the Covid 19 alert poster media in learning to write narrative for fourth grade students of SD Negeri Keseneng. The subjects of this study were 20 students of grade IV SD Negeri Keseneng. Data collection techniques used in this study were observation, interviews, and documentation. Data collection tools in this study were observation guidelines, interview guides, and documentation. Based on the discussion conducted, the researchers concluded that the Covid 19 alert poster media was worthy of being used as a medium in learning to write narratives because it was easy to find, practical, and interesting. In addition, it is also known that students' responses to using poster media are good.
\end{abstract}

Keywords: Poster, Covid 19, narrative writing

\begin{abstract}
Abstrak
Penelitian ini adalah penelitian kuantitatif. Metode penelitian ini menggunakan metodologi penelitian fenomenologi, untuk menggali fenomena yang terjadi dan kebaruannya. Penelitian ini bertujuan untuk mendeskripsikan kelayakan poster waspada Covid 19 sebagai media dalam pembelajaran menulis narasi pada siswa kelas IV SD Negeri Keseneng. Selain itu penelitian ini juga bertujuan untuk mengetahui respon siswa terhadap penggunaan media poster waspada Covid 19 dalam pembelajaran menulis narasi pada siswa kelas IV SD Negeri Keseneng. Subjek penelitian ini adalah Siswa kelas IV SD Negeri Keseneng sebanyak 20 siswa. Teknik pengumpulan data yang digunakan dalam penelitian ini adalah observasi, wawancara, dan dokumentasi. Alat pengumpulan data pada penelitian ini adalah pedoman observasi, pedoman wawancara, dan dokumentasi. Berdasarkan pembahasan yang dilakukan peneliti mengambil kesimpulan bahwa media poster waspada Covid 19 layak digunakan sebagai media dalam pembelajaran menulis narasi karena mudah dijumpai, praktis, dan menarik. Selain itu diketahui pula bahwa respon siswa terhadap penggunaan media poster baik.
\end{abstract}

Kata kunci: Poster, Covid-19, menulis narasi

Social, Humanities, and Education Studies (SHEs): Conference Series https://jurnal.uns.ac.id/shes

p-ISSN 2620-9284

e-ISSN 2620-9292 


\section{PENDAHULUAN}

Pada akhir tahun 2019 ditemukan jenis Virus baru yang menyebar dengan cepat hampir diseluruh permukaan bumi. Hingga World Health Organization (WHO) menetapkan keberadaan virus ini sebagai pandemi (Kompas, 12 Maret 2020). Butuh peran serta semua pihak agar pandemi ini segera berakhir. Tidak terkecuali peserta didik pada pendidikan dasar. Untuk menumbuhkan kesadaran kepada mereka akan bahaya virus ini perlu adanya pemahaman yang harus diberikan kepada mereka.

Pendidikan dasar atau sekolah dasar merupakan momentum awal bagi anak untuk meningkatkan kemampuan dirinya. Dari bangku sekolah dasarlah mereka mendapatkan pengalaman belajar yang kemudian menjadi kebiasaan-kebiasaan yang akan mereka lakukan dikemudian hari. Peran seorang guru sangatlah penting untuk dapat menanamkan kebiasaan baik bagi siswanya. Tidak terkecuali pemahaman tentang Covid 19 dan cara menghentikan penularannya yang baru baru ini menjadi isu yang sangat penting untuk masyarakat Indonesia pada khususnya dan dunia pada umumnya.

Kecakapan abad 21 yang terintegrasi dalam kecakapan pengetahuan, keterampilan, dan sikap serta penguasaan TIK dapat dikembangkan melalui (1) kecapakan berpikir kritis dan pemecahan masalah, (2) kecakapan berkomunikasi, (3) Kecakapan kreatifitas dan inovasi serta (4) kecakapan kolaborasi (Kemendikbud, 2017) Melalui Pembelajaran bahasa Indonesia di sekolah dasar diarahkan untuk meningkatkan kemampuan siswa berkomunikasi baik secara lisan maupun tulisan. Pembelajaran bahasa diarahkan untuk meningkatkan kemampuan peserta didik untuk berkomunikasi dalam bahasa Indonesia dengan baik dan benar baik secara lisan maupun tulis. Pembelajaran bahasa Indonesia, terutama di sekolah dasar tidak akan terlepas dari empat keterampilan berbahasa. Ada empat keterampilan berbahasa yaitu menyimak, berbicara, membaca dan menulis.

Keterampilan berbahasa khususnya menulis dapat dituangkan melalui tulisan. Menulis merupakan sebuah kegiatan yang bersifat produktif yaitu menghasilkan tulisan atau karangan. Menulis merupakan sebuah proses kreatif menuangkan gagasan dalam bentuk bahasa tulis. Kegiatan menulis melibatkan aspek penggunaan tanda baca dan ejaan, penggunaan diksi dan kosa kata, penataan kalimat, pengembangan paragraf, pengelolaan gagasan, serta pengembangan model karangan. Dengan kata lain, dapat dinyatakan bahwa kegiatan menulis melibatkan aspek bahasa dan isi.

Keterampilan menulis salah satunya adalah menulis karangan. Menulis karangan merupakan kegiatan yang membutuhkan pengetahuan dan penalaran yang baik. Mengarang memerlukan pengetahuan dan penalaran yang logis. Mengarang pada hakikatnya adalah mengungkapkan atau menyampaikan gagasan dengan menggunakan bahasa tulis. Mengarang adalah kegiatan untuk mengungkapkan gagasan, ide, dan perasaan yang dituangkan dalam bahasa tulis yang disusun secara teratur dan sistematis sehingga memudahkan pembaca memahami isi pesan yang ingin disampaikan oleh penulis.

Salah satu cara yang dapat dilakukan seorang guru untuk meningkatakan pemahaman terhadap pencegahan penyebaran Covid 19 adalah dengan membuat karangan narasi mengenai pencegahan penularan covid 19 dengan bantuan poster. Penggunaan media poster dipilih karena saat ini media ini sangat mudah dijumpai di tempat umum, diujung gang, bahkan di media sosial dan internet. Penggunaan media poster diharapkan mampu meningkatkan minat dan kemampuan siswa dalam pembelajaran menulis, karena poster dapat menonjolkan kekuatan pesan, visual, dan warna.

Poster adalah media visual yang memberikan informasi tentang ide atau gagasan yang mengajak seseorang baik secara individu maupun kelompok untuk mengikuti atau melaksanakan gagasan tersebut. Poster merupakan gabungan dari 
gambar dan tulisan ringkas dalam suatu bidang gambar yang memiliki nilai - nilai estetis agar dapat menarik perhatian orang yang melihat.

Berdasarkan uraian diatas, peneliti menetapkan rumusan masalah sebagai berikut : Bagaimanakah kelayakan media poster waspada covid 19 dalam pembelajaran menulis narasi pada siswa kelas IV SD Negeri Keseneng? Bagaimanakah respon siswa terhadap memanfaatkan media poster waspada covid 19 dalam pembelajaran menulis narasi pada siswa kelas IV SD Negeri Keseneng?

Manfaat yang dapat diambil dari penelitian ini adalah mengetahui kelayakan media poster waspada covid 19 pada proses pembelajaran menulis narasi pada siswa kelas IV SD Negeri Keseneng. Selain itu juga bermanfaat untuk mengetahui respon siswa setelah memanfaatkan media poster waspada covid 19 dalam pembelajaran menulis narasi pada siswa kelas IV SD Negeri Keseneng.

\section{METODE}

Penelitian ini adalah jenis penelitian deskriptif yaitu penelitian yang bertujuan membuat deskripsi secara sistematis, faktual dan akurat tentang fakta-fakta dan sifatsifat populasi atau obyek tertentu, dengan menggunanakan metodologi riset kualitatif. Bentuk penelitian yang digunakan dalam penelitian ini adalah penelitian kualitatif dengan metode penelitian deskriptif. Teknik dan Alat Pengumpulan Data dalam penelitian ini yaitu observasi, wawancara, dan dokumentasi.

\section{HASIL DAN PEMBAHASAN}

Berdasarkan dokumen yang didapat oleh peneliti, dapat diketahui bahwa poster layak digunakan sebagai media dalam pembelajaran menulis narasi. Hal ini terlihat dari hasil dokumentasi terhadap aktifitas menulis narasi yang dilakukan siswa kelas IV SD Negeri Keseneng selama kegiatan belajar dirumah. Siswa mampu menulis narasi lebih panjang dari biasaya.

Berdasarkan hasil wawancara diketahui bahwa mereka mendapatkan informasi yang memperkaya pengetahuan mereka sebagai bekal menulis narasi dari tulisan maupun gambar yang ada pada media poster. Selain itu keberadaan poster yang menjadi salah satu media himbauan untuk masyarakat dalam rangka pencegahan penularan Covid 19 sangat banyak dijumpai disekitar mereka. Poster poster itu banyak ditempel di tempat tepat startegis di lingkungan rumah mereka, di surat kabar/ majalah, serta di media sosial baik whatsapp/instagram/facebook/ maupun twitter yang sudah tidak asing lagi bagi mereka.

Poin kedua yang menjadi pembahasan adalah respon siswa dalam penggunaan media poster dalam kegiatan menulis narasi. Berdasarkan hasil wawancara yang telah dilakukan melalui aplikasi whatsapp para siswa mengaku antusias menulis narasi menggunakan madia poster. Alasannya poster sangat praktis. Informasi yang mereka butuhkan sudah dipaparkan secara menyeluruh dan holistik dalam satu lembar. Siswa tidak perlu lagi membaca berlembar lembar kertas untuk mendapatkan informasi. Selain itu gambar dalam poster juga menarik mereka untuk membaca tulisan yang menyertainya. "Gambar dalam poster itu unik bu" kata salah seorang siswa ketika diajukan pertanyaan "Apa yang membuatmu ingin memahami informasi dari media poster?"

Selain dari fakta diatas, terdapat fakta lain yaitu antusias para siswa dalam mengerjakan tugas menulis narasi dengan media poster. Alasannya mereka sudah familiar dengan poster karena media poster terutama dengan muatan materi pencegahan penularan Covid 19 sangat mudah mereka temukan. Melalui pembahasan ini diharapkan hasil penelitian ini dapat memberimanfaat dan cara pandang yang benar dalam pemanfaatan poster baik dari segi teoritis maupun praktis, khususnya yang menyangkut upaya meningkatkan hasil belajar siswa. 


\section{SIMPULAN}

Berdasarkan pembahasan yang telah dilakukan peneliti menyimpulkan bahwa poster layak digunakan sebagai media dalam pembelajaran mengarang karena dapat meningkatkan kualitas dan kuantitas karangan yang dibuat oleh siswa. Respon siswa terhadap poster sebagai media dalam menulis narasi sangat baik karena poster dianggap praktis dan mudah dijumpai.

\section{DAFTAR PUSTAKA}

Hildayanti, dkk. 2018. Pengaruh Penggunaan Media Poster Dalam Menulis Karangan Narasi Terhadap Hasil Belajar Siswa Pada Mata Pelajaran Bahasa Indonesia Kelas V SD Negeri 77 Kanaeng Kabupaten Takalar . (JKPD) Jurnal Kajian Pendidikan Dasar. Vol 3 No. 22018

Megawati. Pengaruh Media Poster Terhadap Hasil Belajar Kosakata Bahasa Inggris.

Nawawi, Hadari. 1991. Metode Penelitian Bidang Sosial. Yogyakarta: Gadjah Mada University Press.

Pujasari, Ratu Sarah. 2019. Poster Presentation: Undergraduate EFL Student's Experience. Script Journal Journal of linguistic and english teaching. PISSN: 2477-1880; E-ISSN: 2502-6623 April 2019, Vol. 4 No.1. http://jurnal.fkip-uwgm.ac.id/index.php/Script

Satori, Dja'man, 2010. Metode Penelitian Kualitatif. Bandung: PT. Remaja Rosdakarya.

Suryani,Nunuk ddk. 2018. Media Pembelajaran Inovatif dan Pengembangannya. Bandung : Remaja Rosdakarya.

Yosandika. Ajo Dian. 2018. Pengembangan Media Poster Sebagai Suplemen Pembelajaran Fisika Materi Tata Surya . Indonesian Journal of Science and $\begin{array}{lllll}\text { Mathematics } & \text { Education } & 01 & \text { (3) } & \text { (2018) }\end{array}$ https://ejournal.radenintan.ac.id/index.php/IJSME/index. 